\author{
О.М. Кісельова, О.О. Кузенков, Н.В. Балейко \\ Дніпровський національний університет імені Олеся Гончара
}

\title{
УЗАГАЛЬНЕНІ ПІДХОДИ ДО МОДЕЛЮВАННЯ РОЗПОВСЮДЖЕННЯ COVID-19 НА ЗАКРИТИХ ТА ВІДКРИТИХ АРЕАЛАХ
}

\begin{abstract}
У роботі розглядаються існуючі, запропоновані та узагальнені нові методи та підходи до моделювання розповсюдження інфекційних захворювань на прикладі COVID-19. Для побудови моделей, ідентифікації параметрів, оцінки достовірності результатів використовується оперативна інформація про перебіг епідемії як на теренах окремих областей та міст України, так і держави в цілому. Отримані результати дають змогу оцінити ефективність моделей, підходів та методів при вирішенні різних задач, що можуть враховувати площу ареалів, зовнішні впливи, гендерну, вікову та інші відмінності. В основу класу запропонованих моделей покладено уявлення про популяцію як про множину особин, що сприйнятливі до інфекції, мають імунітет, інфіковані, хворіють та вибули. На основі даних, які протягом 2020-2021 років були зібрані у різних країнах було встановлено основні закономірності, отримано пограничні значення параметрів, при яких відбуваються якісні зміни в системі, досліджено питання можливості штучного втручання в систему та наслідків такого втручання. Проведено змістовний аналіз достовірності моделі та меж застосування результатів такого моделювання.
\end{abstract}

Ключові слова: математичне моделювання, COVID-19, пандемія, епідемія.

\author{
E.M. Kiseleva, O.O. Kuzenkov, N.V. Baleiko \\ Oles Honchar Dnipro national university
}

\section{GENERALIZED APPROACHES TO SIMULATING THE DISTRIBUTION OF COVID-19 IN CLOSED AND OPEN AREAS}

The paper examines the existing, proposed and generalizes new methods and approaches to modeling the spread of infectious diseases using the example of COVID-19. To build models, identify parameters, assess the reliability of the results, operational information about the course of the epidemic is used both on the territory of individual regions and cities of Ukraine and the state as a whole. The results obtained make it possible to evaluate the effectiveness of models, approaches and methods in solving various problems that can take into account the area of areas, external influences, gender, age and other differences.

The class of the proposed models is based on the idea of the population as a multitude of individuals, susceptible to infection, having immunity, infected, sick and retired. Based on the data that were collected in different countries during 2020-2021, the main regularities were established, the boundary values of the parameters were obtained at which qualitative changes in the system occur, the issues of the possibility of artificial intervention in the system and the consequences of such intervention were investigated. A meaningful analysis of the reliability of the model and the boundaries of application of the results of such modeling is carried out.

(C) Кісельова О.М., Кузенков О.О., Балейко Н.В., 2021 
Key words: mathematical modeling, COVID-19, pandemic, epidemic.

\author{
Е.М. Киселева, А.А. Кузенков, Н.В. Балейко \\ Днипровский национальный университет имени Олеся Гончара
}

\title{
ОБОБЩЕННЫЕ ПОДХОДЫ К МОДЕЛИРОВАНИЮ РАСПРОСТРАНЕНИЯ COVID-19 НА ЗАКРЫТЫХ И ОТКРЫТЫХ АРЕАЛАХ
}

В работе рассматриваются существующие, предложенные и обобщенные новые методы и подходы к моделированию распространения инфекционных заболеваний на примере COVID-19. Для построения моделей, идентификации параметров, оценки достоверности результатов используется оперативная информация о ходе эпидемии как на территории отдельных областей и городов Украины, так и государства в целом. Полученные результаты позволяют оценить эффективность моделей, подходов и методов при решении различных задач, которые могут учитывать площадь ареалов, внешние воздействия, гендерные, возрастные и другие отличия.

В основу класса предложенных моделей положено представление о популяции как о множестве особей, восприимчивых к инфекции, имеющих иммунитет, инфицированных, болеющих и выбывших. На основе данных, которые в течение 2020-2021 годов были собраны в разных странах, было установлено основные закономерности, получено пограничные значения параметров, при которых происходят качественные изменения в системе, исследованы вопросы возможности искусственного вмешательства в систему и последствий такого вмешательства. Проведен содержательный анализ достоверности модели и границ применения результатов такого моделирования.

Ключевые слова: математическое моделирование, COVID-19, пандемия, эпидемия.

Вступ. Останні півтора роки Україну та світ сколихнула хвиля захворюваності спричинена розповсюдженням вірусу SARS-CoV-2. Перший спалах відбувся у Китаї. Вкрай рішучі заходи керівництва Китаю мали короткостроковий та, як виявилось, і довгостроковий успіх у боротьбі з інфекцією. Цьому сприяв і політичний устрій, і потужна економіка, і налагодженість процесів у системі охорони здоров'я, але, нажаль, в інших країнах такого успіху не вдалося досягти взагалі.

На сьогоднішній день існує велика база даних про перебіг захворювання, особливості хвороби у різних вікових групах, ускладнення, групи ризику та багато іншого. Але не дивлячись на значне інформаційне підгрунтя боротьба з інфекцією продовжується. Винайдена вакцина спонукає людей вакцинуватись, але навіть медики визнають, що вакцина у деяких випадках може не впливати на нові штами вірусу.

Станом на кінець 2021 року на COVID-19 в Україні, лише офіційно перехворіло більше 3,2 млн. чоловік, щоденно кілька десятків тисяч чоловік інфікуються, більше 76 тис. чоловік померли від COVID-19. Така трагічна статистика збільшує актуальність не тільки медичних інструментів по запобіганню COVID-19 та його лікуванню, але й прогнозуванню швидкості розповсюдження на окремих територіях. Такі прогнози дозволять оцінити готовність 106 
системи охорони здоров'я певного регіону прийняти виклик, оцінити часові та чисельні характеристики спалахів, зрозуміти інші особливості протікання епідемії.

Як показала статистика розповсюдження COVID-19 у різних країнах, перебіг суттєвим чином залежить від замкненості чи відкритості територій. У більш консервативних країнах, із суровими правилами перетину кордонів, а у деяких випадках не тільки кордонів країни але й окремих територій, швидкість розповсюдження інфекції була значно нижче ніж у країнах першого світу де кордони, навіть між країнами, є достатньо умовними.

Огляд проблеми. Протягом майже двох років людство бореться з інфекцією COVID-19. За цей час розроблено велику кількість математичних моделей, які дозволяють достатньо точно спрогнозувати динаміку COVID-19 на окремих територіях, або при виконанні певних додаткових умов. Також існують більш універсальні моделі, які можна застосовувати для більш широкого класу умов, але точність таких моделей, як правило, не буде висока. Причиною такого стану справ є те, що переважна більшість моделей не відображає режими, особливості перебігу та інші якісні особливості процесу протікання хвороби, як індивідуальної так і групової. Здебільшого моделі описують результати нефармацевтичного втручання в процес. 3 одного боку це може бути зумовлено тим, що наукові роботи з математичного моделювання здебільшого охоплюють період до розробки вакцини. А подальші дослідження результатів застосування вакцини здебільшого має більш медичний характер, а у деяких випадках може містити елементи комерційної таємниці в результаті чого не підлягати розголошенню. Дослідження питання впливу нефармакологічних результатів на динаміку розповсюдження COVID-19 дає змогу оцінити результативність таких, здебільшого організаційних заходів, та розробити не тільки профілактичні методи боротьби але й оперативні методи боротьби з безпосередніми наслідками захворювання.

Огляд існуючих методів математичного моделювання динаміки інфекційних захворювань. Історія дослідження інфекційних хвороб налічує сотні, якщо не тисячі років. Але еволюція математичних моделей суттєвим чином залежала безпосередньо від розвитку математичного апарату, методів та алгоритмів. Суттєвий розвиток математичного інструментарію розпочався на початку 20 сторіччя 3 робіт Росса з моделі міграції інфекції $[7,9]$ та іiі носіїв [8]. Макдональду у своїх дослідженнях [5] вдалось побудувати модель розповсюдження інфекції, враховуючи ентомологічні та демографічні особливості. Подальше уточнення моделей відбулось в роботах Хоппенстеда [2], а також ним був розширений і математичний апарат таких досліджень. Широкого розповсюдження набули після публікації Бейлі SEIR та SEI моделі. Після робот Бейлі SEIR та SEI досліджувались в роботах [1, 4], а в роботі [6] було досліджено питання застосування таких моделей при існуванні ентропії за віковим критерієм. Роботи Р.М. Баталіна та В.А. Терлецького [12], а також Л.А. Рвачева $[10,11]$ можна вважати одними 3 найвдаліших результатів дослідження динаміки інфекційних захворювань. Згадані результати дають змо- 
гу досліджувати не просто реальну систему, але й враховувати перетоки в ній та ступінь їх інтенсивності.

Математична модель. До основи дослідження покладено уявлення про популяцію як про множину особин, яку умовно можна поділити на підгрупи «здорових», «інфікованих» та «вибувших». Підгрупи не є ізольованими та існує вірогідність попадання особини $3 ~ i-i ̈$ підгрупи до $j$-ї. Диференціальну модель системи можна записати у загальному вигляді так:

$$
\frac{d x_{j}}{d t}=\sum_{i=1}^{n} A_{j i} \cdot f_{i}(x), \quad j=\overline{1,3},
$$

де $x_{j}$ - чисельність $j$-ї підгрупи, $f_{i}(x)$ - функція, що описує загальні можливості $i$-ї підгрупи до зміни своєї чисельності, а $A_{j i}$ - частка приросту $i$-ї підгрупи, яка потрапляє до $j$-ї. Припускаємо, що $\sum_{j} A_{i j}=1$ при будь-якому $i$. Функція $f_{i}(x)$ відбиває загальновідомий логістичний закон

$$
f_{i}(x)=a_{i} \cdot\left(1-\frac{1}{K} \sum_{l=1}^{n} x_{l}\right) x_{i} .
$$

де $a_{i}$ відбиває можливості підгрупи з індексом $i$ до зростання (занепаду), $K$ ємність ареалу існування популяції. Згідно з (1), (2) приріст підгрупи наближається до нуля у випадку, коли до нуля наближається ії чисельність або коли загальна чисельність усіх підгруп наближається до максимально можливої екологічної ємності середовища $K$.

Для дослідження точок рівноваги системи $(1),(2)$ скористуємося стандартним аналізом за Ляпуновим. Легко бачити, що однією з точок рівноваги є нульова точка (початок координат). Крім того, існує ще нескінченна кількість точок рівноваги, які лежать на площині

$$
\sum_{i} x_{i}=K
$$

Характер розміщення точок рівноваги є досить природним 3 прикладної точки зору. Звісно, в разі повної відсутності особин даної підгрупи виду вони не можуть виникнути з нічого. Якщо ж підгрупи займають одну й ту ж екологічну нішу і не відрізняються за ресурсами, які споживають, довільний їхній розподіл за чисельностями в цій ніші є рівноважним.

Теорема 1: система (1), (2) є виродженою в околі особливих точок стаціонарної гіперплощини (3).

Доведення: загальний вигляд $i j-і ̈$ компоненти матриці Якобі $J$ системи

(1), (2) є таким: $J_{i j}=A_{i j} a_{j}\left(1-\frac{\sum_{k=1}^{n} X_{k}}{K}\right)-\frac{\sum_{p=1}^{n} A_{i p} a_{p} x_{p}}{K}$. Згідно 3 (3) загальний вигляд ij -го компонента матриці Якобі $J$ системи (1), (2) в точках стаціонарної гіперплощини набуде вигляду: $J_{i j}=-\frac{1}{K} \sum_{k=1}^{n} A_{i k} \cdot a_{k} \cdot X_{k}$. Оскільки $J_{i j}$ не залежить безпосередньо від $j$, справедливим $є J_{p i}=J_{h i}, p, h=\overline{1, n}$, iз чого випливає, що 108 
вектор-стовпці матриці Якобі є лінійно залежними, $\operatorname{Det}(J)=0$, а отже, система $\epsilon$ виродженою в особливих точках стаціонарної гіперплощини $\sum_{i=1}^{n} x_{i}=K$. Теорему доведено.

Система (1), (2) для випадку $n=3$ має вигляд:

$$
\left\{\begin{array}{l}
\dot{x}_{1}=\left(A_{11} a_{1} x_{1}+A_{12} a_{2} x_{2}+A_{13} a_{3} x_{3}\right) \cdot\left(1-\frac{x_{1}+x_{2}+x_{3}}{K}\right) \\
\dot{x}_{2}=\left(A_{21} a_{1} x_{1}+A_{22} a_{2} x_{2}+A_{23} a_{3} x_{3}\right) \cdot\left(1-\frac{x_{1}+x_{2}+x_{3}}{K}\right) . \\
\dot{x}_{3}=\left(A_{31} a_{1} x_{1}+A_{32} a_{2} x_{2}+A_{33} a_{3} x_{3}\right) \cdot\left(1-\frac{x_{1}+x_{2}+x_{3}}{K}\right)
\end{array}\right.
$$

Особливими точками системи є точка - початок координат та множина точок, що належать площині

$$
x_{1}+x_{2}+x_{3}=K
$$

ij-й компонент матриці Якобі представлений $J_{i j}=A_{i j} a_{i}\left(1-\frac{1}{K} \sum_{p=1}^{3} x_{p}\right)-\frac{1}{K} \sum_{p=1}^{3} A_{i p} a_{p} x_{p}, \quad i, j=\overline{1,3}$.

За теоремою 1 система (4) є виродженою в околі точок стаціонарної площини (5). Характеристичне рівняння системи (4) має вигляд $t^{3}+b t^{2}+c t+d=0$. Вводячи заміну $t=y-\frac{b}{3}$, отримаємо неповне кубічне рівняння $y^{3}+p y+q=0$, де $p=-\frac{b^{2}}{3}, q=\frac{2 b^{3}}{27}-\frac{b c}{3}+d$, корені якого, згідно з формулою Кардано, обчислюються так: $y=\rho_{1}+\rho_{2}$, де $\rho_{1,2}=\sqrt[3]{ \pm \frac{q}{2}+\sqrt{\frac{q^{2}}{4}+\frac{p^{3}}{27}}}$, при цьому для $\rho_{1}, \rho_{2}$ справедливе наступне $\rho_{1} \cdot \rho_{2}=-\frac{p}{3}$.

Аналітичне представлення меж якісної зміни режимів функціонування системи. У різних літературних джерелах, дослідники по різному викладають аналітичні умови виникнення біфуркацій в системі. Фактично біфуркація виникає при переході визначального параметра системи, який умовно можна назвати ії інваріантою, через критичне значення. Умовним переносом початку координат параметричного простору можна звести визначення біфуркації як перехід визначального параметра через нульове значення. Виходячи $з$ прикладної інтерпретації очевидним стає те, що визначальним параметром може бути обрані власні числа характеристичної матриці які фактично відображають чисельні та якісні межі рівня перетоку між різними підгрупами зазначеної моделі.

Вважаючи аналітичною умовою виникнення в системі біфуркації перехід дійсної частини хоча б одного із власних чисел матриці Якобі системи через нульове значення, для випадку гіперболічної точки початку координат такою 
умовою $\epsilon \operatorname{Det}(J)=0$, а для комплексних $q(J)=0$. Згідно з класифікацією, поданою в [14], для системи (4) можливі такі біфуркації фазового простору, як:

1) «тривісний стійкий вузол» - «стійке сідло» (рис.1);

2) «стійке сідло» - «нестійке сідло» (рис.2);

3) «нестійке сідло» - «тривісний нестійкий вузол» (рис.3);

4) «тривісний нестійкий вузол» - «розбіжний нестійкий фокус» (рис.4);

5) «розбіжний нестійкий фокус» - «збіжний нестійкий фокус» (рис.5);

6) «розбіжний нестійкий фокус» - «розбіжний стійкий фокус» (рис.6);

7) «збіжний стійкий фокус» - «розбіжний стійкий фокус» (рис.7);

8) «збіжний стійкий фокус» - «збіжний нестійкий фокус» (рис.8);

9) «збіжний стійкий фокус» - «тривісний стійкий вузол» (рис.9).

На рис. 1 - 9 представлено фазові портрети системи (4), що ілюструють зміну топології фазового простору при переході параметрів системи через критичні (біфуркаційні) значення. У зв'язку з виродженістю системи в околі стаціонарної площини (5) поведінка фазових траєкторій проілюстрована в околі особливої точки (початок координат).

На рис. 1 подано біфуркаційний випадок при переході одного з коефіцієнтів через нульове значення.

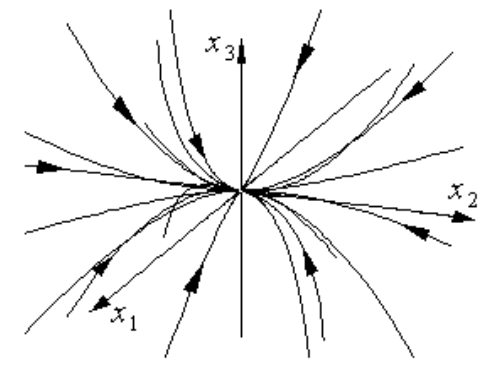

a

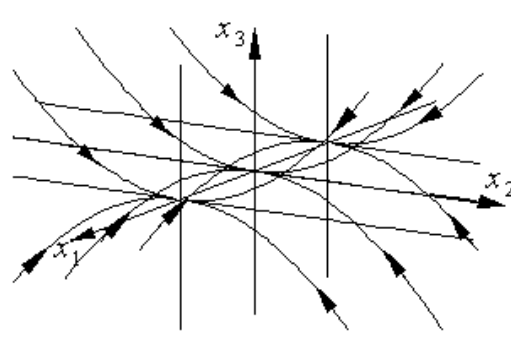

б

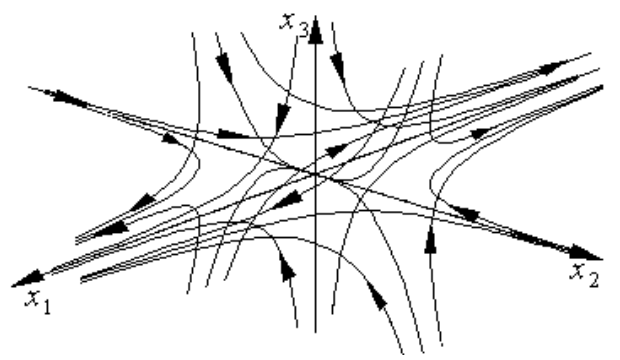

B

Рис.1. Фазовий портрет системи (4) 3 параметрами $A_{11}=0,7 ; A_{22}=0,8$;

$$
\begin{gathered}
A_{33}=0,9 ; A_{i j}=\left(1-A_{i i}\right) / 2 ; i, j=1,2,3 ; i \neq j ; K=100 ; a_{2}=a_{3}=-1 \\
\text { Ta a) } a_{1}=-1,0 ; \text { б) } a_{1}=0,0 ; \text { в) } a_{1}=1,0
\end{gathered}
$$

На рис.1(а) особлива точка (початок координат) є тривісним стійким вузлом, що зумовлено негативним значенням коефіцієнтів репродукції трьох підгруп одночасно. Біфуркація такого типу, будучи найпростішою, зумовлена переходом одного з репродуктивних коефіцієнтів через нуль. У виродженому випадку зростання чисельності підгрупи з індексом 1 зумовлене лише коефіцієнтами перетоку та відбувається лінійно.

При зміні знаку одного з репродуктивних коефіцієнтів знак інших відіграє дуже важливу роль, а при їхній зміні формується такий фазовий простір, що $\epsilon$ топологічно нееквівалентним попередньому (тобто таким, що не може бути отриманий із попереднього шляхом безперервних перетворень). Саме тому доречно виокремити біфуркацію, пов'язану з переходом репродуктивного коефіцієнта $a_{1}$ через нульове значення, що виникає за додаткової умови $a_{2} \cdot a_{3}<0$. Інші параметри були обрані таким чином: 


$$
A_{11}=0,6 ; A_{22}=0,9 ; A_{33}=0,7 ; A_{i j}=\left(1-A_{i i}\right) / 2 ; i, j=\overline{1,2,3 ;} ; \neq j ; K=100 ; a_{2}=2,4 ; a_{3}=-2 ;
$$

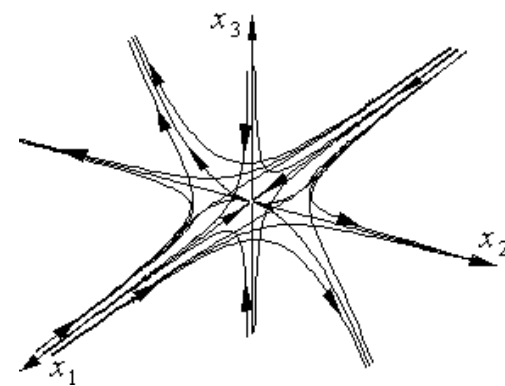

a

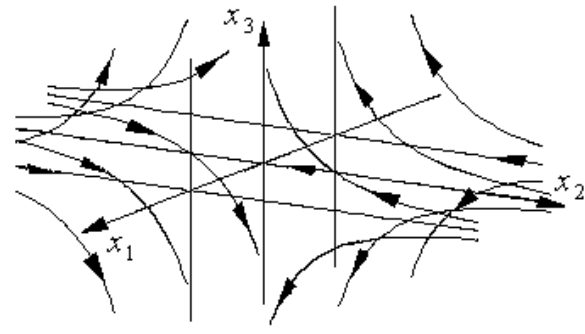

б

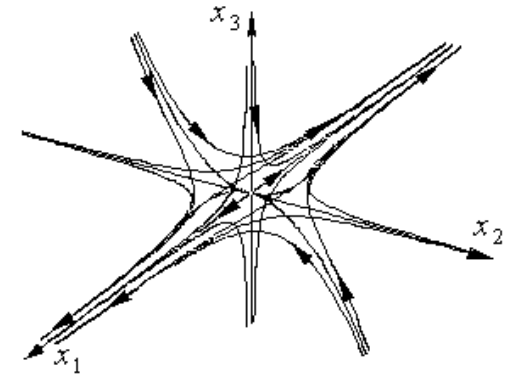

B

Рис.2. Фазовий портрет системи (4) 3 параметрами (6)

та а) $-a_{1}=-1,0 ;$ б) $-a_{1}=0,0$; в) $-a_{1}=1,0$

Випадок, представлений на рис.2(а) відповідає системі, у якій дві підгрупи мають негативний коефіцієнт репродукції. У біфуркаційному випадку в субпопуляції з індексом 1 рівень смертності дорівнює рівню народжуваності, а зміна ії чисельності зумовлена лише коефіцієнтами перетоку. Зазначимо, що як до так і після біфуркації особлива точка (початок координат) є нестійкою, що зумовлено різними знаками коефіцієнтів репродукції $a_{2}$ та $a_{3}$. У біфуркаційному випадку $\left(a_{1}=0\right)$ топологія фазового простору в околі особливої точки (початок координат) $є$ принципово іншою порівняно з біфуркацією типу «тривісний стійкий вузол» - «стійке сідло».

Третій тип можливої біфуркації, що пов'язаний із переходом коефіцієнта репродукції через нульове значення, вирізняється зміною топології фазового простору типу «нестійке сідло» - «тривісний нестійкий вузол».

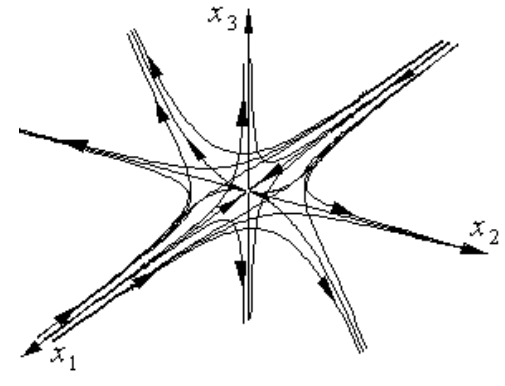

$a$

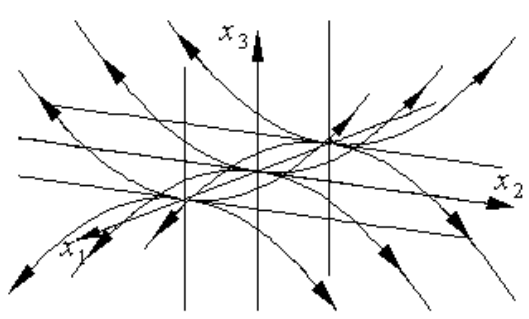

$\sigma$

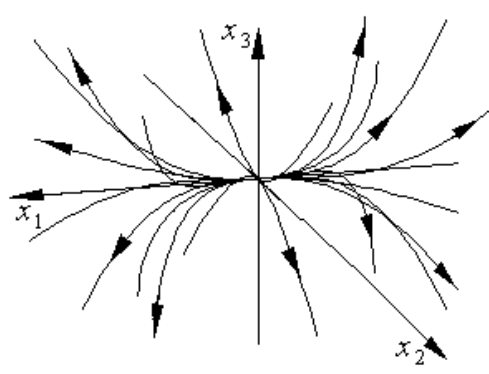

B

Рис.3. Фазовий портрет системи (4) 3 параметрами $A_{11}=A_{22}=0,7, A_{33}=0,8$, $A_{i j}=\left(1-A_{i i}\right) / 2, i \neq j, K=100, a_{2}=a_{3}=2,0$ та a) $a_{1}=-1,0$; б) $a_{1}=0,0$; в) $a_{1}=1,0$

Випадок, представлений на рис.3, хоча і є топологічно нееквівалентним двом випадкам, представленим вище, але з аналітичної точки зору спричинений саме рівністю нулю якобіану в особливій точці (початок координат). Топологія фазового простору при біфуркації «нестійке сідло» - «тривісний нестійкий вузол» має спільні риси з біфуркацією «тривісний стійкий вузол» «стійке сідло» із тією відмінністю, що як до, так і після біфуркаційного стану особлива точка початку координат є нестійкою. 
Наступний тип біфуркації характерний переходом пари власних чисел матриці Якобі на уявну вісь. Аналітичною умовою такої біфуркації є рівність нулю дискримінанта Кардано, характеристичного полінома системи. При цьому топологія фазового простору змінюється 3 «нестійкого двофазновиродженого вузла» на «розбіжний нестійкий фокус». 3 топологічної точки зору така біфуркація вирізняється збігом пари сепаратрис особливої точки початку координат. У випадку, представленому на рис.4(а), усі три підгрупи розвиваються практично незалежно одна від одної, а коефіцієнти перетоку впливають лише на швидкість зростання чисельності тієї чи іншої підгрупи. У виродженому випадку, представленому на рис.4(б), підгрупи з індексами 1 та 2 «обмінюються» такою кількістю нащадків, яка відповідає їхній чисельності. Випадок, представлений на рис.4(в), характеризує стан системи, при якому більша частина приросту обох підгруп переходить до іншої, збільшуючи при цьому її чисельність, що, у свою чергу, зумовлює збільшення чисельності першої підгрупи. Далі будемо умовно називати такі біфуркації взаємопов'язаними.

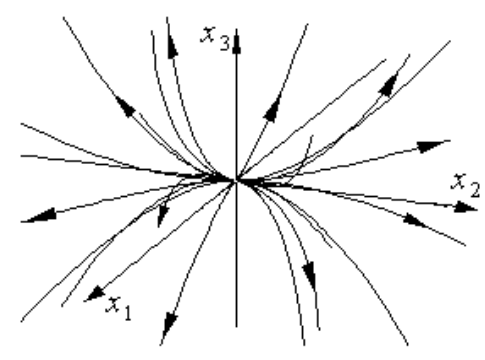

$a$

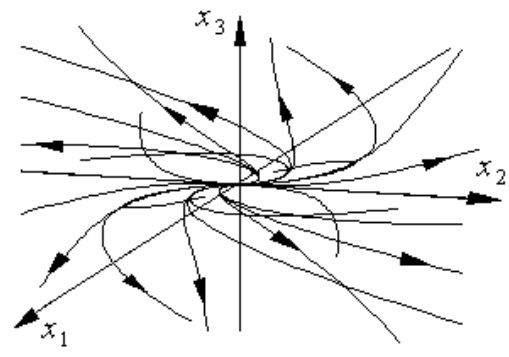

$\sigma$

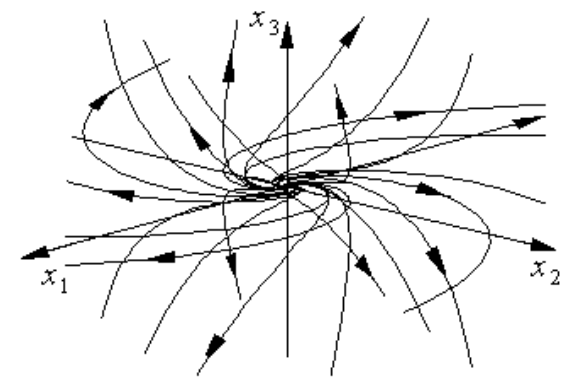

B

Рис.4. Фазовий портрет системи (4) з параметрами $A_{22}=0,4, A_{33}=0,6$, $A_{i j}=\left(1-A_{i i}\right) / 2, i \neq j, K=100, a_{1}=a_{2}=a_{3}=1,0$ та а) $-A_{11}=0,5 ;$ б) $-A_{11}=0,6 ;$ в) $-A_{11}=0,7$

Біфуркаційному випадку, представленому на рис.5, властива еліптична точка початку координат. У даному випадку дві підгрупи $x_{1}$ та $x_{2}$ взаємопов'язані, що визначається парою комплексних коренів характеристичного рівняння. За третьою координатою системи у виродженому випадку динаміка відсутня при $A_{3 i}, i=\overline{1,2,3}$.

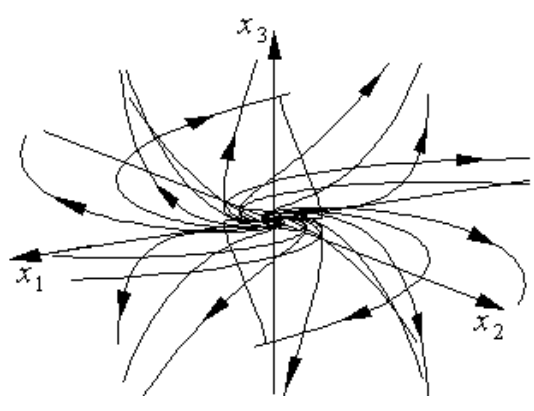

$a$

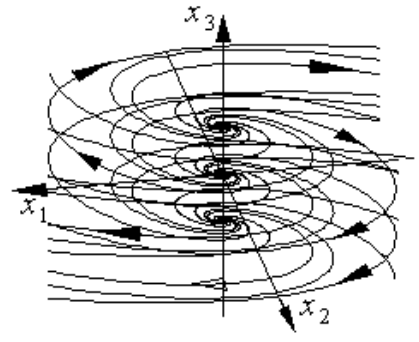

$\sigma$

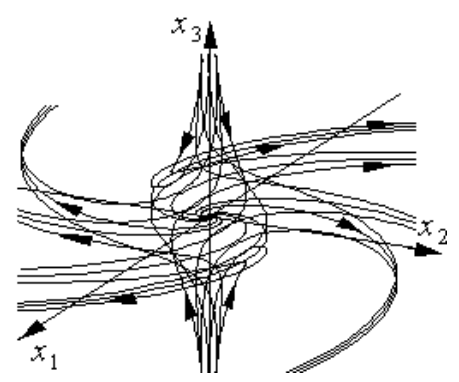

B

Рис.5. Фазовий портрет системи (4) 3 параметрами $A_{11}=A_{33}=0,5, A_{22}=0,6$, $A_{i j}=\left(1-A_{i i}\right) / 2, i \neq j, K=100, a_{1}=a_{2}=1,0$ та a) $a_{3}=1,0 ;$ б) $a_{3}=0,0$; в) $a_{3}=-1,0$ 
У системі, що представлена математичною моделлю (4) можлива ще одна біфуркація нестійкої точки (початок координат). При переході параметра $q$ через нуль взаємопов'язані підгрупи занепадають. У біфуркаційному випадку взаємопов'язані підгрупи з індексами 2 та 3 знаходяться у стані рівноваги та циклічно змінюються за рахунок балансу між відповідними коефіцієнтами переходу $A_{22}+A_{33}=1$. У біфуркаційному випадку рис.6(б) проекції фазових траєкторій на вісь $x_{2}: 0: x_{3}$ утворюють замкнені контури (центр), за якими прямує фазова точка при $t \rightarrow \infty$. При переході через біфуркаційне значення за відповідними координатами система стає стійкою, змінюючи проекцію на відповідну площину з нестійкого на стійкий фокус рис.6(а,в).

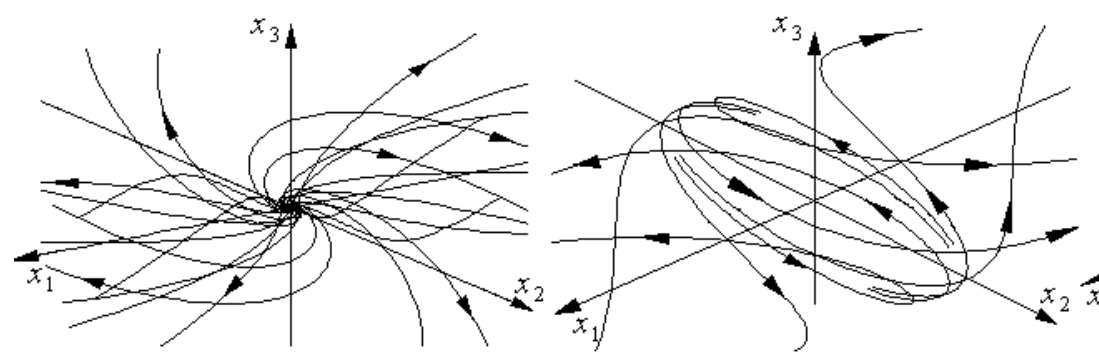

a)

б)

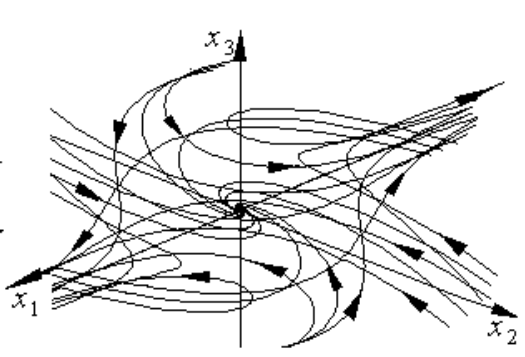

в)

Рис.6. Фазовий портрет системи (4) з параметрами $A_{11}=A_{22}=0,2$, $A_{33}=0,4, A_{i j}=\left(1-A_{i i}\right) / 2, i \neq j, K=100, a_{2}=1,0, a_{3}=-1,0$ та а) $a=1,5$; б) $a=2,0$; в) $a=2,5$

У випадку представленому на рис.7. два із трьох характеристичних чисел належать уявній площині, а дійсна частина комплексно спряжених коренів характеристичного рівняння менша за нуль. Через нульове значення переходить дійсний корінь, спричиняючи тим самим втрату стійкості особливої точки при проекції фазового портрета на вісь $x_{3}$. Із практичної точки зору це означає перехід зі стану «вимирання» до стану «розвиток» тієї з підгруп, яка $€$ умовно незалежною від двох інших.

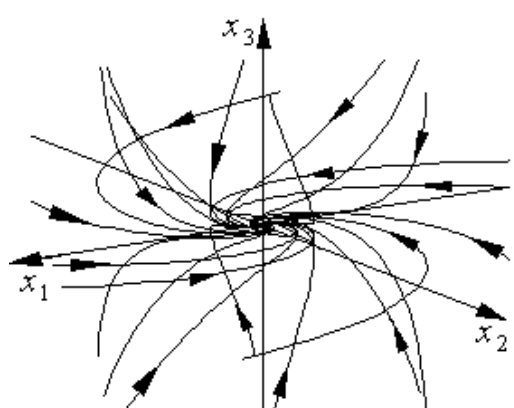

$a$

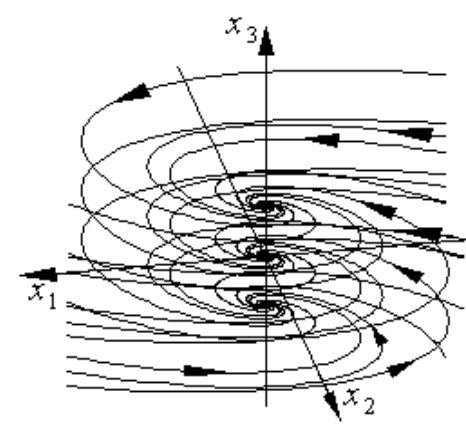

б

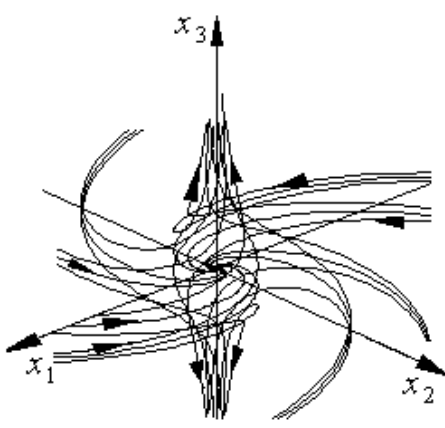

B

Рис.7. Фазовий портрет системи (4) 3 параметрами

$$
A_{11}=0,3, A_{22}=0,5, A_{33}=0,7, A_{i j}=\left(1-A_{i i}\right) / 2, i \neq j, K=100, a_{1}=1,0, a_{2}=-1,0
$$$$
\text { та а) } a_{3}=-1,5 \text {; б) } a=0,0 \text {; в) } a=1,5
$$

На рис. 8 наведено випадок, коли дві підгрупи взаємопов'язані та при переході через біфуркаційне значення параметра $a_{2}=2,5$, ці підгрупи починають розвиватися й циклічно збільшувати чисельність своїх представників - на ві- 
дміну від попереднього випадку (двостороннього занепаду). 3 аналітичної точки зору такий випадок означає перехід дійсної частини пари комплексно спряжених коренів системи через нульове значення, зумовлюючи тим самим втрату стійкості точки рівноваги (початок координат).

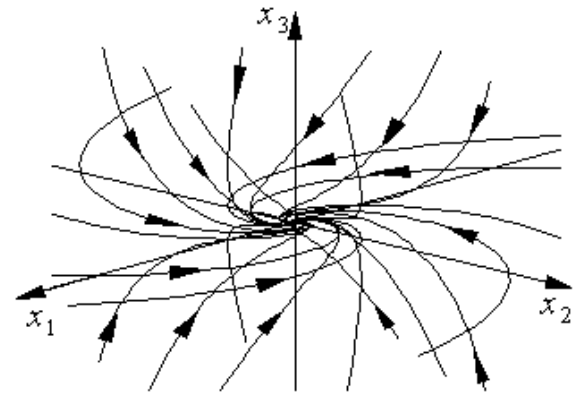

$a$

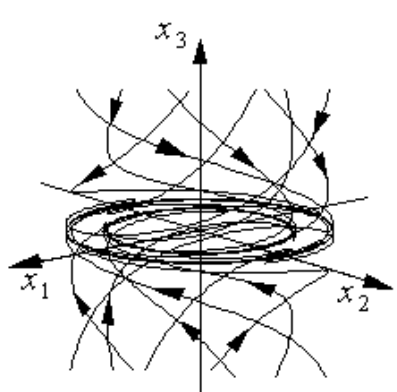

6

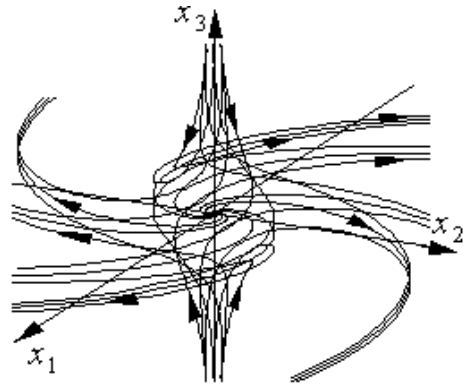

B

Рис.8. Фазовий портрет системи (4) 3 параметрами $A_{11}=0,5, A_{22}=0,3$, $A_{33}=0,7, A_{i j}=\left(1-A_{i i}\right) / 2, i \neq j, K=100, a_{1}=1,0, a_{3}=-1,0$ та а) $a_{2}=2,2 ;$ б) $a_{2}=2,5 ;$ в) $a_{2}=2,8$

Для біфуркаційного випадку, поданого на рис.9, характерне зменшення чисельності усіх підгруп одночасно. При цьому на етапі вимирання дві з трьох підгруп, які були пов'язані між собою, починають розвиватися незалежно одна від одної. Така трансформація системи не змінює загальної картини поведінки системи, а розглядається для отримання повної картини поведінки системи.
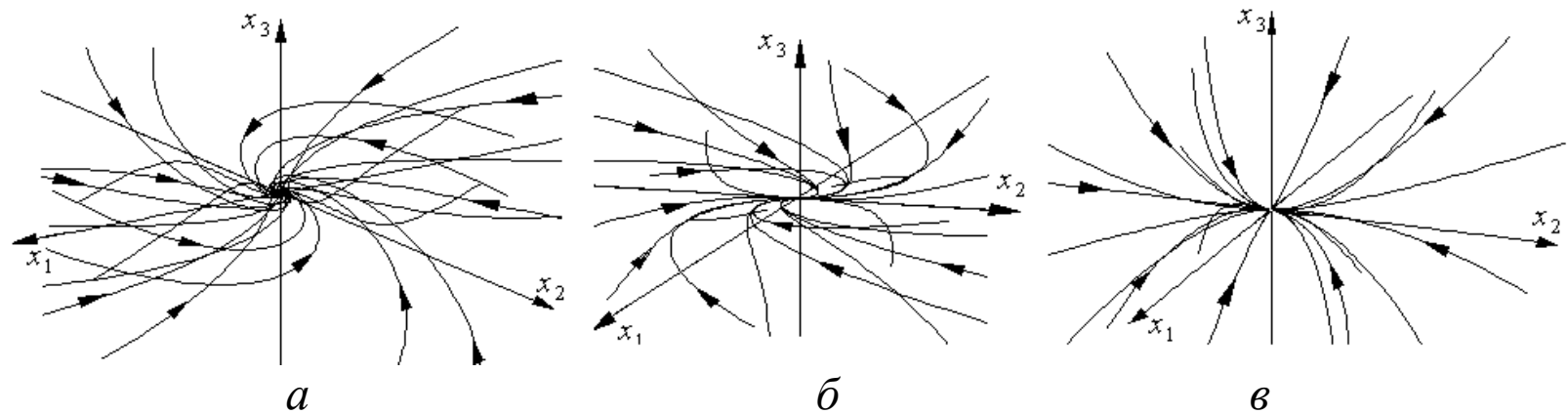

Рис.9. Фазовий портрет системи (4) 3 параметрами $A_{11}=0,4, A_{33}=0,8$, $A_{i j}=\left(1-A_{i i}\right) / 2, i \neq j, K=100, a_{1}=a_{2}=2,0, a_{3}=-1,0$ та a) $A_{22}=0,5$; б) $A_{22}=0,6$; в) $A_{22}=0,7$

Висновки. В роботі наведено результати дослідження математичної моделі динаміки підгруп «здорових», «інфікованих» та «вибувших» особин в контексті захворюваності на COVID-19. В основу моделі була покладена логістична функція в якості базової. Така модель є моделлю між групової динаміки, що відображає перетоки між підгрупами. Це є суттєвою перевагою перед існуючими моделями розповсюдження вірусних хвороб. Було показано, що підгрупи в деяких випадках можуть бути взаємопов'язані. При цьому схильність до розвитку або вимиранню таких підгруп залежить не тільки від їх репродуктивного потенціалу, але й, насамперед, від ступеня взаємозалежності їх репродукцій.

Шляхом аналізу моделі динаміки метапопуляції, що включає декілька підгруп, які конкурують за спільний ресурс, продемонстровано досить різнома- 
нітну потенційну динаміку системи. Незважаючи на вироджений, у певному сенсі, характер моделі, іiі динаміка не є тривіальною, при зміні параметрів системи можливі дев'ять типів біфуркації. Як показали чисельні експерименти, система є досить стійкою щодо збурення іiї коефіцієнтів, і властивості невироджених систем, що можуть бути отримані таким чином, є близькими до системи, яка досліджується.

Хоча у випадку стійкості нетривіальних положень рівноваги кінцеве положення системи залежить від початкових умов, його не можна вважати цілком випадковим. У прямуванні траєкторій системи до рівноваги є певні закономірності, що є предметом подальших досліджень.

\section{Бібліографічні посилання}

1. Gupur G., Li Xue-Zhi, Zhu Guang-Tian. Threshold and Stability Results for an AgeStructured Epidemic Model. Computers and Mathematics with Applications. 2001. Vol. 42. Pp. 883-907.

2. Hoppensteadt F. An age dependent epidemic model. Journal of the Franklin Institute. 1974. Vol. 297. No 5. Pp. 325-333.

3. Hoppensteadt F. Mathematical Theories of Populations: Demographics, Genetics, and Epidemics. Society of Industrial and Applied Mathematics. Philadelphia, PA. 1975.

4. Inaba H. Threshold and stability results for an age-structured epidemic model. J. Math. Biol. 1990. Vol. 28. No 4. Pp. 411-434.

5. Macdonald G. The measurement of malaria transmission. Proc. R. Soc. Med. 1955. Vol. 48. No 4. Pp. 295-302.

6. Park T. Age-dependence in epidemic models of vector-borne infections. The University of Alabama. Huntsville. 2004.

7. Ross R. Report on the prevention of malaria in Mauritius. New York: E. P. Dutton \& Company. 1908.

8. Ross R. The logical basis of the sanitary policy of mosquito reduction. Science. 1905. Vol. 22. No 577. Pp. 689-699.

9. Ross R. The prevention of malaria. London: John Murray, 1910.

10. Рвачёв Л.А. Докл. АН СССР. 180. № 2 (1968). С. 294-296.

11. Рвачёв Л. А. Докл. АН СССР. 198. № 2 (1971). С. 68-70.

12. Баталин Р.М., Терлецкий В.А. Оптимальное управление в моделях эпидемий трансмиссивных заболеваний с SEI-SEIR системами. Известия Иркутского гос.университета Серия «Математика». 2015. Т. 14. С. 18-30.

13. Кісельова О.М., Кузенков О.О., Падалко В.Г. Математичне моделювання розповсюдження COVID-19 у Дніпропетровській області. Питання прикладної математики та математичного моделювання. Вип.20. 2020. С.65-73.

14. Кузенков О.О. Класифікаційна система точок рівноваги лінійної системи диференціальних рівнянь третього порядку. Вісн. Киї. наи. ун-ту імені Тараса Шевченка. Сер. «фіз.-мат. науки». К., 2011. №3. С.106-114.

Надійшла до редколегії 23.06. 2021. 